\title{
How Can Marriage Immigrants Contribute to the Sustainability of the Host Country? Implications from the Leisure and Travel Patterns of Vietnamese Women in South Korea
}

\author{
Suh-hee Choi *(D) and Haeri Jang \\ Department of Geography, Kyung Hee University, Seoul 02447, Korea; haeri.jang@khu.ac.kr \\ * Correspondence: suhhee@khu.ac.kr; Tel.: +82-2-961-0666
}

check for updates

Citation: Choi, S.-h.; Jang, H. How Can Marriage Immigrants Contribute to the Sustainability of the Host Country? Implications from the Leisure and Travel Patterns of Vietnamese Women in South Korea. Sustainability 2021, 13, 1039. https://doi.org/10.3390/su13031039

Received: 24 December 2020

Accepted: 18 January 2021

Published: 20 January 2021

Publisher's Note: MDPI stays neutral with regard to jurisdictional claims in published maps and institutional affiliations.

Copyright: (c) 2021 by the authors. Licensee MDPI, Basel, Switzerland. This article is an open access article distributed under the terms and conditions of the Creative Commons Attribution (CC BY) license (https:// creativecommons.org/licenses/by/ $4.0 /)$.

\begin{abstract}
This qualitative exploratory study focuses on marriage immigrant women and explores the possibility they might contribute to the sustainability of the host country. A sustainable society, the contribution of visiting friends and relatives (VFR) tourism to destination sustainability, information behavior, and fringe stakeholder involvement for sustainable destination management are the focus of this study. Vietnamese marriage immigrant women in South Korea were investigated; the reasons for the investigation include: their increasing numbers, their significance caused by the roles both at the household and the societal levels, and the increased diplomatic ties between Vietnam and South Korea. The narratives of 16 informants about their leisure, hosting of friends and relatives, and information sharing patterns show that Vietnamese marriage immigrant women's leisure and travel facilitate their subjective well-being and the enhancement of social capital, which potentially contribute to a sustainable society. Their hosting experience of the visits of friends and relatives, and its implications for sustainability, are further discussed. Furthermore, their roles as information mediators suggest their potential to contribute to the formation of the host country reputation. Self-appraisal of their unique travel patterns provides implications for involving this group for destination management. We consider both their importance and constraints as contributors to the host country attaining sustainability, and the implications are discussed.
\end{abstract}

Keywords: immigrants' leisure; information sharing; marriage immigrant women; South Korea; sustainability; VFR (visiting friends and relatives); Vietnamese

\section{Introduction}

\subsection{Background}

Permanent and temporary immigration in diverse forms facilitates increased mobility of global actors. This has brought both benefits and challenges to the host countries. It is now generally acknowledged that societies benefit from cultural diversity and the diversity enriches the cultural offering. On the other hand, challenges such as social conflicts and discrimination take place simultaneously. Such social changes have also been documented from the perspective of tourism and leisure [1]. Considering "good health and wellbeing" [2], "reduced inequalities," and "sustainable cities and communities" among the Sustainable Development Goals (SDGs) from the United Nations [3], a stream of tourism and leisure literature has investigated immigrants' subjective well-being through leisure, and explored how this life domain of individuals contributes to social sustainability [4].

From the perspectives of the tourism industry and destination management, the role of immigrants has been acknowledged, though fragmented. Research on the impacts and significance of visiting friends and relatives (VFR) [5], and particularly the contribution of immigrants, has not been integrated with studies of other diversified roles of immigrants as hosts and destination information mediators, and how such behaviors contribute to destination sustainability. 
Furthermore, although scholars have pointed out the utility of engaging immigrants in tourism planning [6], there is still a lack of discussion about how immigrants' insights, understanding, and experiences of domestic leisure and tourism space assist in developing and managing tourism destinations, not only for other immigrants but also for diverse groups of residents and tourists.

\subsection{Vietnamese Marriage Immigrant Women in South Korea}

In investigating the roles of immigrants, this study focuses on Vietnamese marriage immigrant women in South Korea. The fact that there still is no commonly acknowledged definition of marriage immigrant women makes it challenging to conceptualize the term. Its definition and the scope differs slightly depending on the focus, context, and the utility of the definition. Particularly, the legal, social, and academic implications for classifying this group are somewhat different. Legally speaking, according to the Framework Act on the Treatment of Foreigners Residing in the Republic of Korea, marriage immigrants are defined as a foreigner living in South Korea who was or is currently married to a South Korean citizen (i.e., F-6 or F-5 visa holders). The major problem with this legally-bound definition is that it excludes those who have been naturalized. Socially and academically, it is considered adequate to also include naturalized immigrant women for policymaking and academic investigations [7].

Different from migration in many other countries, arranged international marriage, supported by the marriage broker system and governments' policies, has triggered marriage immigration in Asian countries [8,9]. The scholarly focus of marriage immigrant women in Asia are those who got married through some institutional arrangements. Specifically, the majority of Vietnamese marriage immigrant women in South Korea are considered as such "mail-order brides" [10]. In other words, they are assumed to have married a South Korean man utilizing international marriage agencies. Such arranged marriage for a Vietnamese woman involves meeting, in person, a man who visits Vietnam for a short period of time during the arranged dating, deciding to get married quite immediately, and then moving to South Korea after the marriage registration and visa processing. However, recently, the paths for a Vietnamese woman to get married to a South Korean man are reported to have become diversified, especially with an increased number of personal rather than agency-mediated arranged introductions. According to national surveys, in 2015, $56.9 \%$ of surveyed Vietnamese responded that they used a marriage agency to get married. The percentage reduced to $50.9 \%$ in 2018 . However, considering that the percentage of agency-mediated marriages for the entire marriage immigrant sample was $21.1 \%$ in 2018 , this form of marriage is still prevalent among Vietnamese compared with those from other countries $[7,11]$.

Many academic definitions of marriage immigrant woman are presented to investigate the above-mentioned social phenomena, and the definitions are similar across the studies in Asia. For instance, in the context of Taiwanese who married South Asian women, Huang and Mathers [12] defined this group as "those who migrate to another country as a result of marriage" (p. 925). Similarly, in a South Korean context, marriage immigrant women are defined as "foreign-born women who immigrated to South Korea through marriages to Korean men" [13]. Although the definition itself does not assume that the marriage immigrant women are confined to those who are "mail-order brides," the scholarly assumption in investigating this group is that most are married in a rush, and "these women often have a very limited knowledge of their husband's financial status, lifestyle and family circumstances" [12]. Similarly, most marriage immigrants in South Korea are portrayed as having a lack of experience of the host country before they get married [13]. Although this study does not confine the scope of the study to such "mailorder brides," the above-mentioned definition from Chu et al. [13] is adopted because the definition itself incorporates diverse paths by which Vietnamese women marry South Korean men. 
The selection of this demographic group for this study is justified based on its increasing significance to the host country. Most of all, the number of immigrant women and specifically from Vietnam has been increasing and their roles in South Korea are being diversified. Particularly, Vietnamese account for the largest percentage among the marriage immigrant women in South Korea. The instances of marriage between South Korean men and Vietnamese women have soared from 77 in 2000 to 6712 in 2019, accounting in 2019 for $37.9 \%$ of all international marriages between a South Korean man and a foreign woman (Table 1). As of 2019, the number of Vietnamese marriage immigrant women holding F-5 (i.e., permanent resident) or F-6 (i.e., marriage immigrant) visas and not naturalized yet was 40,696 [14], and the number of naturalized Vietnamese marriage immigrant women was 39,628 [15]. Considering potential unofficial instances of non-registered marriages and de facto marriages, the actual number of marriage immigrants is expected to be higher than the official number provided by the government based on the officially registered marriage cases and naturalization. In addition to the increased number of this immigrant group, the political, economic, and societal ties between Vietnam and South Korea have rapidly increased in recent years [16]. Considering not only their number but also their increasing dominance, it is expected that the impacts of this immigrant group on South Korea will be significant, and understanding diverse aspects of their lives as immigrants is expected to provide insights into attaining the sustainability of South Korea, which is rapidly being transformed into a multicultural country [17].

\subsection{Purpose of the Study and the Scope of Sustainability}

Research gaps are found in understanding the life of Vietnamese marriage immigrant women and their role in the host country in attaining sustainability, especially in terms of utilizing leisure and travel as the analytical lenses. There are examples of the contribution of the marriage immigrants to the society in terms of participating in multicultural education, contributing to the enhanced understanding of the immigrants' home countries e.g., [18], and helping other marriage immigrants with acculturation [19]. However, their roles from the perspectives of leisure and travel in relation to sustainability have not been highlighted. Additionally, by examining their hosting patterns during VFR occasions, we seek to discuss the linkage of their VFR to destination sustainability. Furthermore, by exploring what and how they communicate about their travel experience and life in general, we disclose how such roles as mediating between the hosts and guests contribute to the sustainability of the host country. Last, in exploring how the marriage immigrant women uniquely utilize tourism space, implications for destination management are presented.

Research gaps also are found in terms of how Vietnamese marriage immigrants are portrayed; most research has assumed the marriage immigrants as a minority group with a lack of influence on the host country. Many studies about marriage immigrants have portrayed them as a group who is marginalized, suffering from stress originating from violence, discrimination, and acculturation $[8,20,21]$, with the need to be integrated into the mainstream society [22]. Such studies postulate assimilation and social support as the conditions for an enhanced quality of life for the marriage immigrant groups [22]. Notwithstanding the legitimacy of these previous studies, our study does not focus on such well-researched aspects as those in the previous studies. Rather, this study considers the negotiation and resistance of this group and explores both how they are affected by the social system and their active roles in coping with their life conditions which are mostly systematically and interpersonally imposed on them. 
Table 1. Number of International Marriages in South Korea (Source: KOSIS [14]).

\begin{tabular}{|c|c|c|c|c|c|c|c|}
\hline \multirow{2}{*}{ Year } & \multirow{2}{*}{$\begin{array}{c}\text { Total Cases of } \\
\text { International } \\
\text { Marriage }\end{array}$} & \multicolumn{3}{|c|}{ Married a South Korean Man } & \multicolumn{3}{|c|}{ Married a South Korean Wife } \\
\hline & & Foreigners & Vietnamese & $\%$ & Foreigners & Vietnamese & $\%$ \\
\hline 2000 & 11,605 & 6945 & 77 & 1.1 & 4660 & 3 & 0.1 \\
\hline 2001 & 14,523 & 9684 & 134 & 1.4 & 4839 & 5 & 0.1 \\
\hline 2002 & 15,202 & 10,698 & 474 & 4.4 & 4504 & 9 & 0.2 \\
\hline 2003 & 24,775 & 18,750 & 1402 & 7.5 & 6025 & 12 & 0.2 \\
\hline 2004 & 34,640 & 25,105 & 2461 & 9.8 & 9535 & 10 & 0.1 \\
\hline 2005 & 42,356 & 30,719 & 5822 & 19.0 & 11,637 & 28 & 0.2 \\
\hline 2007 & 37,560 & 28,580 & 6610 & 23.1 & 8980 & 61 & 0.7 \\
\hline 2008 & 36,204 & 28,163 & 8282 & 29.4 & 8041 & 61 & 0.8 \\
\hline 2009 & 33,300 & 25,142 & 7249 & 28.8 & 8158 & 49 & 0.6 \\
\hline 2010 & 34,235 & 26,274 & 9623 & 36.6 & 7961 & 67 & 0.8 \\
\hline 2011 & 29,762 & 22,265 & 7636 & 34.3 & 7497 & 93 & 1.2 \\
\hline 2012 & 28,325 & 20,637 & 6586 & 31.9 & 7688 & 180 & 2.3 \\
\hline 2013 & 25,963 & 18,307 & 5770 & 31.5 & 7656 & 279 & 3.6 \\
\hline 2014 & 23,316 & 16,152 & 4743 & 29.4 & 7164 & 283 & 4.0 \\
\hline 2015 & 21,274 & 14,677 & 4651 & 31.7 & 6597 & 432 & 6.5 \\
\hline 2017 & 20,835 & 14,869 & 5364 & 36.1 & 5966 & 586 & 9.8 \\
\hline 2018 & 22,698 & 16,608 & 6338 & 38.2 & 6090 & 587 & 9.6 \\
\hline 2019 & 23,643 & 17,687 & 6712 & 37.9 & 5956 & 639 & 10.7 \\
\hline
\end{tabular}


The purpose of this study is to explore the potential of Vietnamese marriage immigrant women through their leisure, hosting the visits of their friends and relatives, information exchange, and their unique tourism patterns. By doing so, this study aims to find implications for leisure programming, facilitating VFR tourists from Vietnam to South Korea, "listening to" how they communicate [23], and utilizing their tourism pattern for destination management. Specifically, in this study, the significant role of leisure on the Vietnamese marriage immigrants' quality of life and subjective well-being, which is expected to enhance social sustainability, is first explored. Additionally, by examining their hosting patterns during VFR occasions, we seek to discuss the linkage of their VFR to destination sustainability. Furthermore, by exploring what and how they communicate about their travel experience and life in general, we disclose how such roles as mediating between the hosts and guests contribute to the sustainability of the host country. Last, by exploring how the marriage immigrant women uniquely utilize tourism space, implications for destination management are presented.

In investigating the sustainability implications for this study, we do not attempt to link to every aspect of the United Nation's SDGs [3], or all three aspects of the triple bottom line of sustainability (i.e., environmental, economic, or social aspects) which Elkington [24,25] proposed. These two viewpoints are commonly adopted in understanding sustainability comprehensively, where sustainability is defined as "the needs of the present without compromising the ability of future generations to meet their own needs" [26]. Among diverse aspects from which sustainability can be investigated, social sustainability and destination sustainability are illuminated in this study. Social sustainability is conceptualized as the resilience from the destruction of the social and cultural systems, where the resilience is enabled through fulfilling the needs of the diverse community members, including immigrants [4]. Destination sustainability is conceptualized as meeting long-term needs of the stakeholders in a destination economically, socially, culturally, and politically. Sustainability of a host country denotes this at the country level. Among what Ritchie and Crouch [27] suggested, this study considers sustained revenue from tourism, maximized positive and minimized negative sociocultural impacts of tourism development, and political consensus.

The research questions (RQ) of this study are stated as follows:

RQ 1:How does the Vietnamese marriage immigrant women's leisure contribute to the social sustainability of the host country?

RQ 2:How does the Vietnamese marriage immigrant women's hosting of their friends and relatives contribute to destination sustainability?

RQ 3:How do the Vietnamese marriage immigrant women's roles as information mediators contribute to the sustainability of the host country?

RQ 4:How do the Vietnamese marriage immigrant women uniquely utilize tourism space?

\subsection{Significance of the Study}

The significance of this study is as follows: First, this study focuses on the role of Vietnamese marriage immigrants comprehensively-linking leisure, tourism, public diplomacy, and destination management, and focusing on the contribution to sustainability. Second, instead of generalizing Vietnamese marriage immigrants as marginalized, this study applies a stream of research illuminating the active role of this group in contributing to, negotiating with, and resisting the social system [9]. Third, this study highlights the potentials of the marriage immigrant group not only in terms of the consumers of domestic leisure services but also in terms of contributors to the VFR market, both of which are expected to contribute to alleviating risks and recovery from crisis [28]. Therefore, this study is expected to guide policymakers to utilize immigrants in alleviating losses during and after COVID-19, and similar potential crises in the future. 


\section{Literature Review}

The literature review section consists of four parts. The first part reviews research about immigrants' leisure and particularly social integration and subjective well-being as two perspectives which have connected leisure and social sustainability of the immigrants. The second part reviews studies about VFR and its contribution to destination sustainability. We provide a broadened definition of VFR and increased acknowledgement of its contribution. The two streams of VFR research in relation to sustainability and literature about the characteristics of VFR of marriage immigrant women and different types of guests are also reviewed. The third part reviews studies about immigrants as tourism information mediators based on the literature about locals' information behaviors, public diplomacy, and the types of knowledge. The last part in this section reviews studies which emphasized involving immigrants as fringe stakeholders in tourism destination management.

\subsection{Immigrants' Leisure}

Studies have pointed out that only a handful of studies have examined immigrants' leisure. The role of leisure on social sustainability has been even less discussed. In one of the first review articles which focused on immigrants' leisure, Floyd, et al. [29] revealed that, as of 2005, there had been a total of 150 papers in top leisure journals about leisure patterns of those with specific racial and ethnic characteristics, accounting for $4.5 \%$ of the total publications. Specifically, there had been 12 published papers about the impact of immigration on leisure, 20 papers on gender, race and leisure, and 4 papers about the travel patterns of specific ethnic groups. Floyd, et al. [29] also pointed out a limited spectrum of studies about leisure depending on specific racial and ethnic characteristics. More recent studies by Mowatt, et al. [30] and Floyd and Stodolska [31] pointed out a lack of research on leisure and travel of immigrants and diverse minority groups, respectively.

There are two streams of research on the benefits of immigrants' leisure and travel(1) social integration and (2) subjective well-being. Social integration is conceptualized as acculturation to the mainstream society and socialization with the locals and other immigrant groups. Subjective well-being is conceptualized as individuals' own evaluation of the psychological, social, and physical resources that they have, where such resources enable them to react to life challenges [4].

The first stream of research focused on social integration. Such studies have assumed interactions with diverse cultures and acculturation as two of the core benefits of temporary and permanent immigrants' leisure [32]. This is based on the assumed logical connections of (A) leisure and travel, (B) acculturation, (C) subjective well-being, (D) place attachment, (E) social integration, and (F) social sustainability. Most studies, such as Zhang and Long [33], Kim, et al. [34], Gim and Kim [35], Zhang, et al. [36], McClinchey [37], Kim and Lee [38], Sohn and Oh [39], and Kim, et al. [40] have considered fragmented connections of these factors rather than considering them holistically. For example, studies such as Zhang and Long [33] have investigated the connection of (A) leisure and travel and (B) acculturation by emphasizing the role of leisure in facilitating the acculturation of immigrants. Similarly, Kim, et al. [34] found that leisure provides opportunities to socialize with the local citizens, expatriates, and other immigrants from their own and different cultures, and helps acculturation. Studies have also supported the linkage of (D) place attachment, (E) social integration, and (F) social sustainability. Zhang, et al. [36] identified emotional attachment, cultural adaptation, and social participation as the three components of social integration indicators of lifestyle migrants. McClinchey [37] pointed out that emotional attachment to the place by people from diverse backgrounds contributes to the social sustainability. Additionally, there have been studies which only connected (B) acculturation, (C) subjective well-being, and (E) social integration as well as (F) social sustainability. In relation to the context of this current study, studies in South Korea about marriage immigrant women have tended to postulate that (B) acculturation contributes not only to the (C) subjective well-being of immigrants but also to the (E) social integration and (F) social stability of the host country $[38,39]$. This study also goes beyond the 
assumption that (A) leisure opportunities of immigrants facilitate the (E) integration into the mainstream society, as Zhang and Long [33] and Kim, et al. [40] indicated. In other words, this study further argues that leisure also provides opportunities to interact with those from the same cultural background, which enable the immigrants to alleviate the stress of assimilation.

The second stream of research on the benefits of immigrants' leisure and travel focuses on the linkage of leisure, subjective well-being, and social sustainability [2,41]. The linkage of leisure and quality of life has been well documented [41]. Parsons, et al. [2] explored the associations between leisure and subjective well-being, which lead to the fulfillment of a portion of the Sustainable Development Goal of the United Nations [3].

Specifically, there are only a handful of studies about the benefits of the leisure of marriage immigrant women. Sharaievska, et al. [42] is one of such studies which investigated this linkage by focusing on the role of leisure on marital satisfaction in multicultural family contexts. There are fewer which have chosen South Korea as a study area. According to a recent review by Lee [43], there had been only 37 such articles in South Korea between 2008 and 2017, with the first article published about marriage immigrants' leisure in 2008. Lee's [43] review revealed that in South Korean society the focus of understanding immigrants' leisure has been on the impacts of leisure participation on quality of life, happiness, social acculturation, leisure satisfaction or dissatisfaction, leisure patterns and constraints, and policies. In investigating these factors, the focus has not been marriage immigrant women. Furthermore, although studies on marriage immigrant women have pointed out subjective well-being and social integration as the outcomes of leisure, how these women further contribute to social sustainability has not been explored.

\subsection{Hosting Friends and Relatives and Sustainability}

In recent years, the scope of VFR in defining the term has tended to incorporate diverse aspects of interactions between visitors and diversified types of residents. The definitions have become broader, acknowledging that the possible types of trips as well as the hostguest relationships have become diversified. Griffin [5] thus included VFR as all types of tourism experiences, regardless of any designated indication of the main purpose of trips, types of accommodations, and activities that involve any form of visitor-resident relationships. With the extended definition of VFR and with an increased acknowledgement of its impacts, the scope of the impacts of VFR has been considered more widely. Backer [44] emphasized that the impacts of visiting friends and relatives are underestimated and that the process by which such VFR tourism provides benefit to the tourism destination needs to be explored further.

The present study goes beyond the examination of the general benefits of VFR and further explores the benefits from the perspectives of destination sustainability. The linkage of visiting friends and relatives (VFR) and sustainability has been investigated from the perspectives of destination sustainability and specifically social capital. With regard to the former, Ritchie and Crouch [45] pointed out 'family ties' as one condition for a sustainable competitive destination. In so arguing, they emphasized the potentials of professional and personal networks of immigrants and further suggested that VFR triggered by such personal networks should be importantly considered. In the same vein, studies have revealed the benefits of VFR in that it attracts visitors to the destinations which are not touristic [46] and that this form of tourism enables visitors to have more authentic, real experiences of the destination by experiencing the destinations from the insiders' perspectives, exploring hidden gems of the destination areas [5,47]. Economically, VFR has been known to be a viable market which benefits the destination in that VFR tourists visit longer and more frequently than other types of tourists [46] and that they spend more money than the amount that can be captured from the statistics [46].

With regard to the latter, studies have suggested that VFR contributes to enhancing social capital. According to Putnam [48], social capital is defined as "features of social organization, such as trust, norms, and networks that can improve the efficiency of society 
by facilitating coordinated actions" (p. 167). In the context of VFR tourism, in defining social capital, Hung, et al. [49] relied on Poortinga's [50] definition, which is "the extent and intensity of association links or activities, as well as members' perceptions of support, reciprocity, sharing, and trust in a community" (p. 256). Such definitions indicate that social capital implies the notion of a personal network, a support system, bonding and linkage, and availability of resources from personal contacts. Academic investigations of the role of VFR in relation to social capital mostly have not expanded the discussion to sustainability. For instance, focusing on the visit of immigrants to the hometown from which they emigrated, where the immigrants' family and friends still reside, Hung, et al. [49] explored how VFR helps to attain the social capital of their friends and relatives back home. Griffin and Glover [51] asserted that social capital is built during the hosting experience. Such social capital not only includes tangible resources shared with the personal network but also includes emotional benefits of the hosts in that the visits of friends and relatives assist overcoming challenges of life in the destination region, such as homesickness and acculturation stress.

Furthermore, in examining how such benefits differ by the types of hosts and the guests, limited studies have focused on marriage immigrant women, especially those from Southeast Asia living in South Korea. In identifying the marriage migration-led VFR, we adopt the assertion that migration and tourism are integrated and that migration and VFR reinforce each other [52]. The nexus of marriage-led migration and tourism, and further, the potential of their contribution to sustainability is investigated in this study. Specific investigations on marriage immigrants after considering the characteristics of the host and the guest countries have been limited. One such study was done by Moon, et al. [53] about Vietnamese marriage immigrant women in South Korea. Moon, et al. [53] assumed marginalized positions of Vietnamese immigrant women and emphasized constraints of VFR and its acculturation benefits, especially when Vietnamese marriage immigrant women had VFR opportunities to visit their hometowns in Vietnam with parents-in-law. Additionally, the VFR market study by the Korea Tourism Organization [54] found that the economic benefit of the Southeast Asian VFR market to South Korea appears not to be so productive because this market perceives costs of travel as a significant barrier to visit South Korea and often gives up, postpones, and minimizes the number of visits. Because a lack of market value has been identified, there has been little consideration of how such VFR experiences of marriage immigrant women contribute to the sustainability of the destination.

Furthermore, studies have suggested the potential of different hosting patterns by the types of guests, especially relatives in contrast to friends $[55,56]$. Seaton and Tie [56] revealed that visiting relatives (VR) is different from visiting friends (VF) in that VR travelers tend to visit frequently and repeatedly, are accompanied by children, are relatively old, travel during the holiday season, tend to stay long, tend to be sightseeing and entertainment-oriented, and are motivated heavily by family events. Similarly, Yousuf and Backer [55] compared these two groups of guests (VF and VR) based on the purpose of visits, benefits, and challenges, and hosting patterns. Their findings suggest that VR and VF affect the sustainability of the destination in different ways.

\subsection{Immigrants as Tourism Information Mediators}

Studies that have highlighted immigrants as tourism information mediators and their potentials to assist sustainable development of the destination can be approached from three streams-(1) studies on locals as tourism informants, (2) public diplomacy studies which highlighted the diplomatic roles of such mediating agents, and (3) tacit knowledge development of immigrants and their channeled information-sharing of the host country.

First, the role of locals as tourism informants has been highlighted from the studies on locals as tourism ambassadors [57] and on the host's roles in the shared economy platforms such as Airbnb [58]. Temporary and permanent immigrants are known to benefit the destination from information behavior perspectives in that they are likely to present 
positively about the host region $[59,60]$. Additionally, studies have reported VFR hosts' significant roles as tourism informants during hosting and the guests' expectations of the hosts about having unique and localized information provided [47].

Second, there has been a growing interest in the roles of laypersons who contribute to public diplomacy as informants about a host country [61,62]. Public diplomacy is defined as official and unofficial strategies to interact with foreign publics or international actors [63]. The scope of the actors and the way of communication has been expanded from one-way communication from the government to the foreign public, to diversified, two-way communication which facilitates not only achieving diplomatic goals of the government but also seeking mutual benefits of the government and the foreign public [64]. Especially, the role of "grassroots diplomats", who could be any citizens who are nonpolitical actors and could affect the reputation of both home and host countries through communication, is expected to increase with the development of information technology that facilitates convenient information-sharing across borders [65,66]. Immigrants and their communicative roles have been important in that they have the potential to enhance the attractiveness of the host region [61]. Specifically, perceived levels of knowledge of the immigrants about the host country, their confidence about the quality of such information [67], and other facilitating factors affect the activeness of information-sharing of temporary or permanent immigrants with international information recipients.

Third, the role of immigrants as the agents of information-sharing based on their codified and tacit knowledge, especially the latter, provides implications on how they contribute to the sustainability of the host country. The knowledge accumulated by immigrants can be classified into codified and tacit knowledge. While codified knowledge is expected to be widely available, tacit knowledge is likely to be what can be uniquely accumulated by immigrants. Immigrants are known to accumulate tacit knowledge-embrained (i.e., conceptual and cognitive domains accumulated through experiences and training), encultured (i.e., tacit knowledge about cultural and social norms enhanced by socialization and acculturation), embedded (i.e., understanding of social contexts and system which form everyday routine), and embodied (i.e., knowledge stored in body and mind). Based on the acquisition of social norms, language, and hidden rules during the process of accumulation, immigrants have the potential to build unique forms of knowledge which contribute to knowledge transfer to their personal networks - friends and relatives at home and other immigrants and potential immigrants. From the perspectives of leisure and travel, such channeled knowledge is expected to contribute to sharing knowledge and opinions from insiders' perspectives about the host country and the destination. Based on such a type of knowledge accumulated, (temporary) immigrants are likely to build confidence about local information and would communicate actively about such knowledge with those back home [67].

\subsection{Involving Immigrants in Tourism Destination Management}

Literature has suggested the utility of involving immigrants in tourism destination management. There has been a consensus that the immigrants' travel patterns are unique in that they have knowledge about the leisure and tourism space in both their home and the host regions and thus they develop unique patterns to utilize leisure and tourism space in the host region [68]. Furthermore, as they are likely to be ready to host friends and relatives, they explore the local space in advance and gain knowledge about the area to host them [59]. Triggered by such hosting occasions, they have opportunities to be interested and explore their own local areas, which lead to unique knowledge about tourism offerings [5]. Such new types of exploration of the local place are expected to enable the hosts to blur the boundaries between home and away and to rediscover the local areas and thus enhance place attachment of the immigrant hosts $[5,69]$. Furthermore, Mattsson and Cassel [70] highlighted the roles of immigrant tourism entrepreneurs in terms of developing new ways to attract foreign visitors and using international-channeled professional and personal networks to facilitate efficient development. 
Considering such unique roles, Khazaei, et al. [6] encouraged including immigrant groups as fringe stakeholders in tourism planning, acknowledging their unique destination experiences, ties, and knowledge. Their adoption of the term 'fringe stakeholder' is based on the discussions of the stakeholder theory and specifically Hart and Sharma [71], who defined fringe stakeholders as those who are less known, less powerful, peripheral, or "the poor, weak, isolated, non-legitimate, disinterested, and even non-human" (p. 8) actors who affect or are affected by the organization's decision making. Similarly, Lalicic and Önder [72] asserted that inclusive and customized approaches should be pursued in involving first-generation immigrants in tourism planning, and the government should seek sustained participatory approaches to hear such stakeholders' opinions. In doing so, they proposed that smart tourism planning approaches using information and communication technology would assist the incorporation of such fringe stakeholders.

\section{Methods}

This study follows the philosophical assumption of constructivism, which assumes that the realities are constructed based on diverse perspectives of individuals. Thus, instead of generalizing the patterns, the data collection and analysis were conducted to listen toand interpret as outcomes of interactions with the informants-how individuals make sense and subjectively understand the reality. The researchers acknowledge that the narratives are the outcomes of the interactions between the researchers and the informants, and that the data analysis involves interpretations of the researchers which are affected by their positionalities. Last, methodologically, inductive methods were adopted in finding patterns of the narratives based on the research questions [73,74].

Because of the exploratory nature of this study and its aim to investigate how the informants understood the reality and made sense of their way of thinking and behaviors, qualitative methods were used for data collection and analysis. Further, it was necessary to guide the informants during the interviews in relation to the research questions; thus, individual semi-structured interviews were conducted for the current study. Purposeful sampling and, specifically, homogeneous sampling was used when identifying and approaching the sample [73]. Specifically, considering the aim and the scope of the study, informants were recruited based on three main criteria to fit with the topic of this study-(1) Vietnamese marriage immigrant women (including F-5, F-6 visa holders, and naturalized Vietnamese) (2) who had married a South Korean man and (3) had been living in South Korea.

Potential interviewees were approached through multicultural family support centers and the researchers' personal network. Potential informants were Vietnamese women who had married a South Korean man at about the time they had moved to South Korea. Although the recruited informants were homogeneous in that they met the three abovementioned criteria, in order to gain rather comprehensive insights into the perceptions and experiences of the focus of our investigations, we did not restrict Vietnamese immigrant women participants based on specific backgrounds in terms of how they met their South Korean husband, prior and current work experiences, educational levels, age, number and age of children, and their hometowns. Most informants were confined to those who were living in the urban area; those who were living in the rural areas were excluded.

The interviews were conducted in July and August 2020 by the second author, who is a bilingual speaker of Korean and Vietnamese, in either of the two languages in which the interviewees felt more comfortable. If necessary, for clarification, both languages were used simultaneously during the interviews. All the interviews were conducted for at least one hour in the places where the interviewees felt comfortable, including a cafe, a multicultural center, an office, or partly online using remote conferencing tools, depending on the COVID-19 situation and the interviewees' preferences, especially during the followup interviews. The second author, having majored in the Vietnamese language and its culture, was knowledgeable about Vietnamese and Vietnam and was fluent in the language of the informants. The interviewees were informed that the interviewee's identifying 
information would not be shared. When the interview participants were recruited, the objectives of the research project were thoroughly illustrated.

The interview guiding questions were based on the research questions of the study and included the participants' overall leisure patterns, hosting experiences of their friends and relatives, information behaviors about South Korea, and perceived uniqueness of their traveling pattern. The first author was academically experienced with conducting a similar study in another Asian country. Thus, both her research experience and the research questions of this study, in combination with guiding questions and the review of the literature by the time the interviews were initially conducted, were considered in developing the guiding questions. Following Patton [73], the guiding questions for this exploratory study involving semi-structured interviews were not detailed in order not to confine the narratives to narrow themes based on what the researchers expected about the responses. Although the guiding questions did not change drastically during the process of the interviews, as the interviews proceeded, prompts increasingly included the feelings and the meanings of their leisure, travel, and information behaviors. If needed, follow-up interviews were conducted, mostly online.

Based upon the interviewees' consents, all the interviews were recorded, transcribed, and translated, if necessary, to Korean for textual data analysis. In addition to this, notes were taken before, during, and after the interviews for further information collection. Interview scripts were reviewed and read by both authors before being coded based on the identification of repeated expressions and statements relevant to the scope and the focus of the research. Codes were synthesized and themes were then identified [75]. In doing so, following Patton [73], the authors focused on how each informant described her experience and thought about her leisure, hosting friends and relatives, and information searching and sharing patterns. The authors concentrated on finding meanings from the narratives rather than seeking to quantify the qualitative data, see [73].

A total of 16 interviewees participated in the interviews. Considering the exploratory nature of this study, as well as the scope of the current study, following Patton [73], the data were saturated in answering the research questions. The informants' identities were anonymized and thus are presented as ID numbers in the following sections.

\section{Findings}

\subsection{Social Sustainability through Immigrants' Leisure}

The linkages of the informants' expression of the benefits of leisure to the social sustainability were observed at three levels-intrapersonal, interpersonal, and social. At the intrapersonal level, the informants highlighted the role of leisure-time spending in enhanced subjective well-being. Stating that she enjoys leisure time for herself by asking her friends to babysit for her child, ID 13 stated, "I need time for myself. If I am with my baby, it is not a day for me to take a rest".

At the interpersonal level, the benefit of leisure was highlighted as an opportunity to build family solidarity, to have new destination experiences, and to socialize with other Vietnamese immigrant women, which hinted at the contribution of leisure on social sustainability through enhanced family and community bonds. First, the informants appreciated the solidary that they built through leisure and travel with their South Korean husband, children, and sometimes in-law family members. Many had experienced leisure and travel with their husbands and shared how the husband contributed to this aspect of life. ID 9 disclosed going out with her husband to try ethnic foods, sharing a part of the life that both the husband and the wife like: "Both I and my husband like Indian foods, so I go to eat Indian curry, and we go out to eat Vietnamese foods". ID 11 stated, "My husband took me to many places". In illustrating how her husband provided her with opportunities to explore activities, she pointed out that "he took me to the multicultural center, prepared all the documents, and helped to find a Korean teacher. I go to the Korean academy thanks to my husband". 
Second, the informants appeared to provide opportunities for the husband to have new leisure options that he did not try before marriage, and some informants stated that the husband showed gratitude for such new opportunities, suggesting the contribution to social sustainability through enhanced family bonds. ID 7 stated,

My husband says he would not have been to such touristic places without me. So, he has been around together with me. He said that in the past [before marriage] he watched baseball games, slept for a long time, ordered foods by himself or ate convenience foods, being addicted to the smartphone and watching TV a lot on weekends, not going out of the house or drinking with friends.

Third, many mentioned spending time with a mother-in-law. While some expressed that leisure and traveling with in-laws was a burden and lacked freedom, others expressed the time spent together as an opportunity to learn about South Korea, suggesting leisure as a tool for social integration. ID 6 said, "I go to the house of my mother-in-law often, eating together, learning how to cook". ID 7 experienced similarly, saying, "cooking with my mother-in-law, learning together".

Fourth, another distinctive interpersonal aspect was that the informants had a strong tendency to socialize with other Vietnamese immigrant women instead of those of other ethnicities or origins or from other countries or Korean natives. Last, institutionally supported or not, many leisure experiences involved learning experiences about South Korea, its language, and the culture. Institutionally, 'multicultural centers' were repeatedly mentioned by the informants as the agent which provided opportunities for the informants to learn about South Korea, leisure and travel options, and socializing opportunities, which consistently suggesting the role of leisure in social integration and social sustainability.

The findings also show different patterns of social integration through leisure. Different from some cases in other countries, intercultural encounters and especially the opportunities were limited for Vietnamese marriage immigrant women to meet Korean natives extensively through leisure. However, leisure experiences provided opportunities to socialize and explore the host country, both locally and non-locally, thus providing chances to have a first-hand experience to learn about South Korea. Specifically, social capital through networking was built not by extending personal networks with those from other ethnic groups but by socializing with other Vietnamese in similar stages of acculturation to the host country. Considering that the informants did not express the need to be integrated into the mainstream society and were not desperate to socialize with other immigrants from different countries or Korean natives, the results contrast to the assumption of leisure and travel activities for immigrants as mainly acculturation opportunities [53,76] and the assumption that failure to acculturate means failure to be incorporated into the mainstream culture, facing discrimination and alienation [53]. The findings rather conform to Zhang and Long [33] and Kim, et al. [40] in that in-group social interactions among the immigrants are facilitated through leisure.

\subsection{Destination Sustainability Attained through VFR}

VFR was not experienced so often by the informants, yet unique patterns suggested its contribution to destination sustainability and enhanced social capital. The most remarkable pattern in the context of VFR among the informants was that there was a clear difference between hosting family members and hosting friends. Overall, family members tended to stay longer than their friends. One significant pattern was about long-term visits of parents, especially their mothers. This was facilitated by the South Korean law that allows long-term stay of the family members of the marriage immigrants from Vietnam. ID 3 illustrated, "my mother stayed here for two months when my baby was born".

The mothers of Vietnamese immigrant women mostly helped with caring for their grandchildren and with domestic chores, and some of them worked outside the home during the stay. Mostly, immigrant women's mothers who had such obligations expressed hardship with traveling domestically in South Korea during their stay. Only a few local excursions were facilitated. For instance, ID 4 regretted a lack of opportunities for her 
mother to travel domestically because of the daughter's situation of having just delivered a baby and the mother's main motivations to visit South Korea as a caregiver:

My mother came [to South Korea]. She helped me for three months when my second child was born in 2014. It was not tourism but she simply came to South Korea to help me. As she came to South Korea to help me, the only travel we conducted was to visit the Han River just once. Although she stayed for three months, we were not able to travel a long-distance because the baby was just born.

On the other hand, most friends who visited South Korea used package tours, so their "visiting friends" encounters took place during free time during the packaged tours. ID 8 illustrated such an experience:

I have hosted my friend only once. A friend of mine came to South Korea to travel. She told me she was then in Yongsan District. So, I brought her to my house. And then we ate outside, had a good time, and then I took her back to Yongsan.

The findings showed that, for the Vietnamese friends back home, the existence of their married friends in South Korea motivated them to visit South Korea. Even so, because of the systematic constraints of traveling as independent tourists, their friends mainly joined group package tours; thus, they would be documented as non-VFR tourists in tourism statistics. Considering Munoz et al.'s [77] suggestion to differentiate the motivations of travel and the main purpose of the trip, such groups could be a hidden market with motivations to see the host immigrants, yet the main purpose might be documented as sightseeing. This implies that with fewer visa restrictions towards Vietnamese, the potential to have an increased number of individual visiting-friends (VF) tourists would be expected. Key constraints of VFR appeared to be time and especially the cost for travel. The results conform to suggestions from the Korea Tourism Organization [54] that urged lowering barriers to travel for this geographic market by lowering costs and visa restrictions. The informants, such as ID 12, were expecting promotions to this market such as price discounts and some external assistance, such as from the government, to lower the cost barriers to travel. ID 12 expressed such a desire, saying:

In fact, I want to visit many places. However, in some tourist attractions, the entrance fee is very expensive. That discourages me from visiting such places. I think it would be great if there could be price discounts for marriage immigrants.

The results also show that, as was also pointed out by Backer [44] and Yousuf and Backer [55], VFR experiences not only involved touristic activities but also included familyrelated activities for the visit of family members and socializing activities for the visit of friends. This further suggests VFR as opportunities to enhance social capital, which was also emphasized by Hung, et al. [49]. This study presents the possibility that social capital is strengthened through long-term visits of parents, especially mothers, in that visits further provide opportunities for mothers to extend personal connections and work opportunities in the host country. More importantly, findings from the current study revealed that family involvement in care during the VR occasions was consistent with findings from previous studies, such as Backer [44], Yousuf and Backer [55], Munoz, et al. [77], and Janta and Christou [78], which described constraints to traveling with hosts during the stay and at the same time functioned as strengthening family ties. Conforming to Munoz, et al. [77], the aspects of obligations as family members of the immigrant women triggered family members to visit, and visas and regulations which facilitated long-term stay for family members reflected social, cultural, and political relationships of the home and away.

Last, in addition to Yousuf and Backer [55], who identified differences of VFR by the types of hosts at the interpersonal levels, the findings from this study further emphasize that in addition to considering patterns of personal encounters at the individual level, it is also important to consider systematic regulations that differentiate the visiting patterns of different types of guests. Specifically, findings from this study showed that the lengths and types of trips were regulated by the different types of visas and trips offered to family 
members and friends. In this case, extended stay was facilitated to the direct family members while friends' individual trips were limited, and this affected VFR patterns.

4.3. Self-Concept about the Informants' Roles as Information Mediators, Information Behavior, and Implications to Sustainability

A variation existed in terms of how self-conscious the informants were about their roles as information mediators about South Korea and its leisure and travel options. ID 3 expressed that she had never recognized herself as a mediator of information about South Korea, saying, "I have never thought about the role [of myself] as a mediator of South Korea and Vietnam". On the other hand, ID 2 was more aware of problems and had a strong self-concept about her role as an information-sharer showing real married life as an immigrant woman in South Korea:

I want to tell my Vietnamese friends about the life in South Korea. The life is not that glamourous like in the Korean movies. I think the reason why there are many international marriages is because of the dramas. Yes, they cause us to build too great of a positive image about the life in South Korea, and once we come here, the life is not like that. Because of that, the possibility to get divorced is high. What they see and experience is different from what they imagined in Vietnam. So, they get shocked and are likely to get divorced. So, I would like them to get prepared and talk about such things. Vietnamese people have that fantasy: Once they come to South Korea, all the husbands are rich and have a lot of money, so they can do whatever they want, and they feel like becoming a Cinderella. They tend to want things like that. So, I am talking about all the real aspects of the life in South Korea to my friends.

ID 5 echoed this position. She recognized it as problematic to see other Vietnamese expressing a desire to live in South Korea after having formed an image through the media:

Life in South Korea looks good in the movies. But, I think, wherever you live, life is all the same. There are good and bad things. So, if I hear others say that they want to come to South Korea simply after watching the movies, I say, no.

The informants were motivated to share information that only they could uniquely share. ID 4 exemplified some insiders' tips for traveling as the topic to share with Vietnamese friends back home: "[I share] where you can take a lot of pictures in Yeouido, enjoying flowers, fireworks festivals [which] people do not know about if I don't share them intentionally". ID 13 also selected information to share which would be "of interest or remarkable".

Many expressed their activeness in information sharing, especially positive aspects about South Korea. This was about everyday life, such as eating Kimchi. ID 3 stated that she talked about "Kimchi because it is a good food, good for the health, and especially I am good at making Kimchi, so I boast about it". This selectivity appeared based on the desire to make family members and friends not worry about the immigrant woman's life in South Korea, and also based on a real positive impression about South Korea.

For many informants, their information sharing was triggered by the inquiry of other Vietnamese about South Korea and its tourism, and they showed selectivity in the way they shared about life in South Korea and its tourism. ID 2, for instance, was asked about the travel options in South Korea by friends in Vietnam:

They ask which place is good when they come to South Korea. They say they want to travel to South Korea. They ask about accommodation options and how much something costs in Vietnam Dong. The most frequently asked question is about must-eat places in South Korea.

ID 7 echoed ID 2 and explained the high awareness about South Korea among her Vietnamese friends back home: 
Vietnamese know much about Korean singers and actors, more than me. They are that interested. Also, they are interested in Korean cosmetic products and want to visit South Korea. They do come to South Korea and buy those products a lot.

Similarly, ID 9 recognized the interest and the desire of Vietnamese acquaintances to learn about South Korea: "People around me ... are interested in South Korea. Because I am in South Korea, people around me ask me to tell them about South Korea". ID 13 tended to receive inquiries about the travel options by potential travelers or immigrants to South Korea: "Those who want to come to South Korea or those who want to travel to South Korea come to ask me how to get there". ID 14 also was queried much by her friends "about the life in South Korea". Because of the nature of 'everyday conversation' between the immigrants and those in their home country, information sharing about their leisure and travel was not done separately from that about other aspects of life.

As a result of such information sharing, the informants felt happy with the opportunity to talk, and they received positive feedback. When ID 4 shared pretty travel pictures of South Korea, her Vietnamese friends and family said, "Oh, this place is pretty" or "I also want to go to South Korea". Echoing ID 4, when ID 8's friends saw the pictures she shared of domestic traveling in South Korea, they expressed, "I also want to go," and "I really want to visit South Korea sometime," or "Why is South Korea so good?"

Such conversations appeared to trigger the desire to travel not only with those who are in Vietnam but also with those who live in South Korea. ID 7 tended to recommend to others to visit local destinations, saying "I have been to Anmyeondo. There are many shells and sushi is fresh and tasty. When I told my friends about that, they said, 'Shall we go together next time?'"

Overall, the findings show that, consistent with the findings from previous studies $[59,60]$, information behaviors of marriage immigrants assisted with the sustainability of the host country in that they selected mostly positive information about the host country to share proactively with friends and family back home. Noticeably, the findings show that recognizing some issues about the destination triggered the informants to talk proactively about life experiences different from those portrayed through media. This implies that based on their experiences in both home in Vietnam and the host country, these marriage immigrants can play unique roles as information mediators correcting biased information and selecting information to share that accommodates the information needs of the information recipients back home in Vietnam, thus enabling potential marriage immigrants and travelers to reduce trial-and-error in moving to or visiting South Korea.

The findings also suggest that the informants had diverse information behaviors in balancing information-sharing about life in South Korea and its tourism. Most did not consciously separate the occasion for talking about these two domains. However, some appeared to share tourism information somewhat forcefully, expecting positive feedback from the audience.

\subsection{Perceived Unique Traveling Patterns and Their Implications}

The informants emphasized their unique traveling patterns in South Korea. In doing so, they emphasized superiority in their tourism information by going to "local" places unknown to other foreigners and where only Koreans go such as "an Ice Museum" where ID 3 visited with her child or the places that "other Vietnamese people do not know about". ID 3 tended to avoid places where other Vietnamese tourists like to go: "It seems Vietnamese people like too much about the places such as Namsan Tower. So, I go to places that are less famous-the places that are enjoyable yet people do not know about".

The informants thought it a privilege to be able to travel domestically with more relaxing schedules compared to other Vietnamese tourists who mostly have to join a packaged tour. ID 9 compared her friend's travel experience in South Korea to her own:

I had a friend of mine who came to visit South Korea [who joined a package tour], and the schedule was very tight. She visited many places in Seoul on the first day and other 
places on the second day, Jeju Island on the third day, Busan the next day, and back to Seoul the last day. I would have been very tired if I had followed that schedule.

On the other hand, as she was "living here, we can go to those places whenever we want to go, and we don't need to be in a hurry. If we want to go somewhere, we can take a car". She emphasized that she knows "more about South Korea and travels more cheaply" than other ordinary Vietnamese tourists. ID 13 expressed that famous touristic places are "boring," contrasting her travel pattern with other Vietnamese package tourists:

My travel pattern is very different from others. I don't go to famous places among other Vietnamese tourists. Those who come from Vietnam select famous places and visit such places only: They go to famous places such as Nami Island and Namsan Tower. For me, such places are not interesting.

The findings from this study revealed the informants' self-perception about their unique understanding of the leisure and tourism space of the host country. Additionally, the marriage immigrants appeared to build confidence through a few enabling factors, such as enough time to explore the host country, being able to use resources from the two countries, family as a factor enabling more frequent and unique travel, and the help of the multicultural centers that provide leisure and travel opportunities and companions with whom to spend time for such activities. Thus, findings suggest the need in destination management to incorporate this fringe stakeholder group's unique tourism patterns for tourism management, especially in terms of developing tourism experiences that could target the growing Southeast Asian market.

\section{Conclusions}

\subsection{Implications of the Study}

This study explored the potential role of Vietnamese marriage immigrant women in attaining the sustainability of South Korea as a host country by focusing on their leisure and travel patterns. Qualitative inquiries have shown the context of their roles.

First, leisure assisted with the informants' subjective well-being and further enhanced collective societal well-being through leisure activities with people around them, including family members and other social networks, mostly other Vietnamese. Social sustainability through personal interactions thus appeared to be attained not necessarily through assimilation to the host country and socializing with native Koreans or immigrants with other cultural backgrounds, as had been the focus of previous studies.

Practically, this study shows a secondary benefit of Support Centers for Multicultural Families (SCMF) by the Ministry of Gender Equality and Family, urging to reconsider the roles of the government's support for acclimation from the perspective of leisure and travel. In previous studies, the role of these multicultural centers was emphasized as the place for 'direct' acclimation such as learning the language and the culture of South Korea as well as family care and career assistance [79]. However, such studies have not highlighted the secondary benefits of the programs. This study is significant in showing that the support by the social system not only directly helps with providing programs for cultural and life assistance, but it also provides secondary benefits to the marriage immigrant women by offering leisure and travel opportunities.

Second, from the perspective of hosting friends and relatives, this study implies the potential contribution of the Vietnamese marriage immigrant women to the sustainability of the host country through the enhancement of social capital enabled by the visits of their friends and relatives. Considering the market size of marriage immigrant women's friends and family, their desire to travel, and the social significance of this group, government and tourism industries would do well to consider how to provide better opportunities for this group for VFR tourism. Noticeably, considering that group package tourists are not likely to be classified as VFR tourists, in this situation, there are hidden VFR tourists who joined such group tours yet in fact were motivated by the existence of the marriage immigrant women in the host country. This implies that the real impacts of Vietnamese immigrant 
women in South Korea in triggering the visits of friends might be currently underestimated and their impacts might be more significant than expected; thus, they might be contributing to the sustainability of the host country, as Ghaderi [46] also suggested.

Third, clues were also found about the contribution of them as 'grassroots diplomats' in enhancing impressions or correcting information about Korea and its tourism, which could steer the perceptions and behaviors of the information recipients. Considering the active and unique role of Vietnamese marriage immigrants as information mediators, tourism marketers and public diplomacy practitioners are suggested to (1) understand their information sharing pattern about the host country, (2) acknowledge their impacts on sustainable reputation management of the country and its destination, (3) further segment information sharers based on their activeness and positivity, listen to them more carefully, and (4) efficiently manage information shared by such grassroots diplomats, as Payne [65] and Payne, et al. [66] also suggested.

Last, this study explored the contribution of Vietnamese marriage immigrant women based on how they believe they explore the leisure and tourism space uniquely. Considering their perceived uniqueness in their exploration patterns, findings imply that, as Khazaei, et al. [6] and Lalicic and Önder [72] also suggested, Korean destination management organizations could involve this immigrant group as fringe stakeholders in discovering hidden leisure and travel options for residents and tourists. Particularly, their unique experiences could hint at optimized development of tourism itineraries for both the Vietnamese geographical market and the Southeast Asian market, considering the cost, travel time, and shared values across countries in this geographical region. The potential has been thus revealed for this group to contribute to the sustainable development of tourism destinations by diversifying and optimizing tourism options.

\subsection{Contributions of the Study}

This study contributes to the body of knowledge in that it understood the contributions of marriage immigrants to the host country through the unique lenses of leisure and travel, social sustainability, and destination sustainability. In doing so, a combination of the concepts of social capital, public diplomacy, and fringe stakeholders was adopted and applied to the under-researched context of Vietnamese marriage immigrants in South Korea. A literature review was conducted about immigrants and leisure, VFR, and stakeholder involvement in destination management. As a result of such investigations, going beyond portraying Vietnamese women as marginalized people who need to be assimilated into the mainstream society, their active and significant roles in assisting to attain the sustainability of the host country were comprehensively revealed.

\subsection{Limitations and Future Studies}

Some limitations of this study warrant future development of this topic and utilizing different methodologies by adopting different philosophical assumptions than the current qualitative inquiry. This study focused on Vietnamese marriage immigrants to South Korea and explored the potential contribution of this group. However, this study, done qualitatively, is of an exploratory nature, and more detailed investigations about each domain identified in this study are needed.

Furthermore, this study focused on the Vietnamese only, and marriage immigrants from different cultural backgrounds and social status, especially those with fewer visa restrictions and financial constraints, are expected to show somewhat different ways of leisure and travel. This implies that different patterns of contribution to sustainability of the host country are expected by different immigrant groups. Future studies thus could also consider other variables such as sociocultural and demographic variables, individuals' social support, place of residence, immigration status, experience of discrimination, and ethnicity in segmenting marriage immigrants, considering the suggestion from Yoo, et al. [79]. 
In so doing, different philosophical assumptions, especially positivist, than the current study grounded by constructivism could be adopted if future studies aim to find more generalizable results. If so, a few related topics, such as the social networking pattern of the marriage immigrants, could be investigated using diverse methodologies such as multimedia social network modeling e.g., [80,81].

Last, regionally, as only the host country was the focus in this study, the roles of Vietnamese marriage immigrant women to the sending country-Vietnam-were not focused on. Future studies could be done about the sending country and also together with the host country to gain a more comprehensive understanding of the perceptions and behaviors of the hosts and guests and to explore their contribution to the sustainability of both countries.

Author Contributions: Conceptualization, S.-h.C.; methodology, S.-h.C.; data analysis, S.-h.C. and H.J.; data curation, S.-h.C. and H.J.; writing-original draft preparation, S.-h.C.; writing-review and editing, S.-h.C. and H.J.; project administration, S.-h.C.; funding acquisition, S.-h.C. All authors have read and agreed to the published version of the manuscript.

Funding: This work was supported by a grant from Kyung Hee University in 2020 (KHU-20201236).

Informed Consent Statement: Informed consent was obtained from all subjects involved in the study.

Data Availability Statement: The data are held with the authors.

Conflicts of Interest: The authors declare no conflict of interest.

\section{References}

1. Stodolska, M. Research on race, ethnicity, immigration, and leisure: Have we missed the boat? Leis. Sci. 2018, 40, 43-53. [CrossRef]

2. Parsons, H.; Houge Mackenzie, S.; Filep, S.; Brymer, E. Subjective well-being and leisure. In Good Health and Well-Being; Leal Filho, W., Wall, T., Azul, A.M., Brandli, L., Özuyar, P.G., Eds.; Springer: Cham, Switzerland, 2020; pp. 678-687.

3. United Nations. Transforming Our World: The 2030 Agenda for Sustainable Development; A/RES/70/1; UN General Assembly: New York, NY, USA, 2015.

4. Gallant, K.; Tirone, S. A 'Good life without bells and whistles': A case study of immigrants' well-being and leisure and its role in social sustainability in Truro, Nova Scotia. Leisure 2017, 41, 423-442. [CrossRef]

5. Griffin, T. Visiting friends and relatives tourism and implications for community capital. J. Policy Res. Tour. Leis. Events 2013, 5, 233-251. [CrossRef]

6. Khazaei, A.; Elliot, S.; Joppe, M. An application of stakeholder theory to advance community participation in tourism planning: The case for engaging immigrants as fringe stakeholders. J. Sustain. Tour. 2015, 23, 1049-1062. [CrossRef]

7. Ministry of Gender Equality and Family. The National Survey of Multicultural Families. 2018. Available online: http://www. mogef.go.kr/mp/pcd/mp_pcd_s001d.do?mid=plc503\&bbtSn=704820 (accessed on 6 January 2021).

8. Park, S.; Morash, M. An exploratory study of influences on vulnerabilities to family violence among Vietnamese wives who marry South Korean men. Crit. Criminol. 2017, 25, 1-19. [CrossRef]

9. Kim, Y.; Shin, H. Governing through mobilities and the expansion of spatial capability of Vietnamese marriage migrant activist women in South Korea. Singap. J. Trop. Geogr. 2018, 39, 364-381. [CrossRef]

10. Lee, H.-K. International marriage and the state in South Korea: Focusing on governmental policy. Citizensh. Stud. 2008, 12, 107-123. [CrossRef]

11. Jo, H.; Hoang, T.V.H. A comparative analysis of the motivation for marriage and relations with their family in Vietnam depending on marriage methods-A case of Vietnamese marriage migrant women. Discours. Policy. Soc. Sci. 2017, 10, 143-166. [CrossRef]

12. Huang, Y.C.; Mathers, N.J. Postnatal depression and the experience of South Asian marriage migrant women in Taiwan: Survey and semi-structured interview study. Int. J. Nurs. Stud. 2008, 45, 924-931. [CrossRef]

13. Chu, M.S.; Park, M.; Kim, J.A. First childbirth experience of international marriage migrant women in South Korea. Women Birth 2017, 30, e198-e206. [CrossRef]

14. KOSIS. International Marriage Statistics. Available online: http://www.index.go.kr/potal/main/EachDtlPageDetail.do?idx_cd= 2430 (accessed on 6 January 2021).

15. Ministry of the Interior and Safety. Foreign Residents by Local Governments in 2019. Available online: https://www.mois.go.kr/ frt/bbs/type001/commonSelectBoardArticle.do?bbsId=BBSMSTR_000000000014\&nttId=80781 (accessed on 6 January 2021).

16. Koo, S.-V. South Korea and the transitional economies of Southeast Asia: A case study of South Korea-Vietnam economic relations. In ASEAN and KOREA; ISEAS Publishing: Singapore, 2018.

17. Draudt, D. Multiculturalism as state developmental policy in Global Korea. In Korea and the World: New Frontiers in Korean Studies; Brazinsky, G.A., Ed.; Rowman \& Littlefield: London, UK, 2019; pp. 157-178. 
18. Park, C.; Gwangju Dong-gu, marriage migrants initiate a ‘Da-I-Eum project'. GJT News. 7 September 2020. Available online: http:/ / www.gjtnews.com/news/articleView.html?idxno=317221(accessed on 6 January 2021).

19. Ministry of Gender Equality and Family. Establishing Foundations for the Social Participation of Marriage Immigrant Women by Vitaliazing Self-help Meetings. Available online: http://www.mogef.go.kr/nw/enw/nw_enw_s001d.do?mid=mda700\&bbtSn= 706210 (accessed on 6 January 2021).

20. Chae, S.M.; Park, J.W.; Kang, H.S. Relationships of acculturative stress, depression, and social support to health-related quality of life in Vietnamese immigrant women in South Korea. J. Transcult. Nur. 2014, 25, 137-144. [CrossRef] [PubMed]

21. Kim, B.; Son, K.B. Factors affecting the self-rated health of immigrant women married to native men and raising children in South Korea: A cross-sectional study. BMC Women's Health 2020, 20, 210. [CrossRef] [PubMed]

22. Cho, Y.J.; Jang, Y.; Ko, J.E.; Lee, S.H.; Moon, S.K. Acculturation, acculturative stress, and depressive symptoms in international migrants: A study with Vietnamese women in South Korea. J. Immigr. Minor. Health 2018, 20, 1103-1108. [CrossRef] [PubMed]

23. Cull, N.J. Public diplomacy: Seven lessons for its future from its past. Place Brand. Public Dipl. 2010, 6, 11-17. [CrossRef]

24. Elkington, J. Cannibals with Forks-Triple Bottom Line of 21st Century Business; New Society Publishers: Stoney Creek, CT, USA, 1998.

25. Elkington, J. The triple bottom line: Sustainability's accountants. In Environmental Management: Readings and Cases; Russo, M.V., Ed.; SAGE: Los Angeles, CA, USA, 2008; pp. 49-66.

26. Brundtland, G. Report of the World Commission on Environment and Development: Our Common Future; United Nations General Assembly Document A/42/427; United Nations: New York, NY, USA, 1987.

27. Ritchie, J.R.B.; Crouch, G.I. A model of destination competitiveness and sustainability. In Destination Marketing and ManagementTheory and Applications; Wang, Y., Pizam, A., Eds.; CABI: Cambridge, MA, USA, 2011; pp. 326-339.

28. World Tourism Organization. Tourism Congestion Management at Natural and Cultural Sites; WTO: Madrid, Spain, 2004.

29. Floyd, M.F.; Bocarro, J.N.; Thompson, T.D. Research on race and ethnicity in leisure studies: A review of five major journals. J. Leis. Res. 2008, 40, 1-22. [CrossRef]

30. Mowatt, R.A.; Johnson, C.W.; Roberts, N.S.; Kivel, B.D. "Embarrassingly White": Faculty racial disparities in American recreation, park, and tourism programs. Sch. J. Leis. Stud. Recreat. Educ. 2016, 31, 37-55. [CrossRef]

31. Floyd, M.F.; Stodolska, M. Scholarship on race and ethnicity: Assessing contributions to leisure theory and practice. J. Park Rec. Admin. 2019, 37, 80-94. [CrossRef]

32. Hasmi, H.M.; Gross, M.J.; Scott-Young, C.M. Leisure and settlement distress: The case of South Australian migrants. Ann. Leis. Res. 2014, 17, 377-397. [CrossRef]

33. Zhang, Y.; Long, M. The role of Yum Cha (Cantonese morning tea) in the integration process among interprovincial migration in China. Leis. Stud. 2015, 34, 59-66. [CrossRef]

34. Kim, J.; Heo, J.; Lee, C. Exploring the relationship between types of leisure activities and acculturation among Korean immigrants. Leis. Stud. 2016, 35, 113-127. [CrossRef]

35. Gim, M.-O.; Kim, M.-J. Leisure desire and leisure behavior of the married Korean-Chinese immigrant women. Int. J. Tour. Sci. 2011, 35, 97-120.

36. Zhang, H.; Yan, L.; Lee, H.M.; Yang, Q. Social integration of lifestyle migrants: The case of Sanya snowbirds. Curr. Issues Tour. 2020, 23, 2825-2838. [CrossRef]

37. McClinchey, K.A. Social sustainability and a sense of place: Harnessing the emotional and sensuous experiences of urban multicultural leisure festivals. Leisure 2017, 41,391-421. [CrossRef]

38. Kim, H.; Lee, Y.-S. Life satisfaction among marriage-immigrant women: Focusing on social context and social discrimination. Korean J. Soc. 2013, 47, 177-209.

39. Sohn, Y.M.; Oh, S.S. Research trend on leisure and acculturation of immigrant. J. Leis. Stud. 2012, 10, 1-27. (In Korean)

40. Kim, J.; Park, S.-H.; Kim, M.; Kim, S.Y. Exploring issues and strengths of cross-cultural marriage among Korean immigrants. Health Care Women Int. 2017, 38, 1095-1114. [CrossRef]

41. Iwasaki, Y. Leisure and quality of life in an international and multicultural context: What are major pathways linking leisure to quality of life? Soc. Indic. Res. 2007, 82, 233-264. [CrossRef]

42. Sharaievska, I.; Kim, J.; Stodolska, M. Leisure and marital satisfaction in intercultural marriages. J. Leis. Res. 2013, 45, 445-465. [CrossRef]

43. Lee, J.-H. A systematic review of 10 years of research on the leisure of marriage migrant women in Korea: Its progress and future directions. J. Tour. Sci. 2019, 43, 205-229.

44. Backer, E. VFR travel: It is underestimated. Tour. Manag. 2012, 33, 74-79. [CrossRef]

45. Ritchie, J.R.B.; Crouch, G.I. The Competitive Destination: A Sustainable Tourism Perspective; CABI: Wallingford, UK, 2003.

46. Ghaderi, Z. Visiting friends and relatives (VFR) travel: The case of Iran. In VFR Travel Research; Backer, E., King, B., Eds.; Channel View Publications: Bristol, UK, 2015; pp. 109-120.

47. Shani, A.; Uriely, N. VFR tourism: The host experience. Ann. Tour. Res. 2012, 39, 421-440. [CrossRef]

48. Putnam, R.D. Making Democracy Work. Civic Traditions in Modern Italy; Princeton University Press: Princeton, NJ, USA, 1993.

49. Hung, K.; Xiao, H.; Yang, X. Why immigrants travel to their home places: Social capital and acculturation perspective. Tour. Manag. 2013, 36, 304-313. [CrossRef]

50. Poortinga, W. Social relations or social capital? Individual and community health effects of bonding social capital. Soc. Sci. Med. 2006, 63, 255-270. [CrossRef] [PubMed] 
51. Griffin, T.; Glover, T.D. The development of social and cultural capitals for immigrant hosts of VFR travellers. Leis. Sci. 2020, 1-19. [CrossRef]

52. Williams, A.M.; Hall, C.M. Tourism and migration: New relationships between production and consumption. Tour. Geogr. 2000, 2, 5-27. [CrossRef]

53. Moon, B.-Y.; Yang, S.-H.; Lee, T.J. Married immigrant women's VFR tourism as the way to ethnic minority group acculturation J. Tour. Cult. Chang. 2019, 17, 544-561. [CrossRef]

54. Korea Tourism Organization. Inbound VFR Market-Survey and Research; KTO: Seoul, Korea, 2014.

55. Yousuf, M.S.; Backer, E. Hosting friends versus hosting relatives: Is blood thicker than water? Int. J. Tour. Res. 2017, 19, 435-446. [CrossRef]

56. Seaton, T.; Tie, C. Are relatives friends? Disaggregating VFR travel 1994-2014. In VFR Travel Research; Backer, E., King, B., Eds.; Channel View Publications: Bristol, UK, 2015; pp. 28-45.

57. Edwards, D.; Cheng, M.; Wong, A.I.K.; Zhang, J.; Wu, Q. Ambassadors of knowledge sharing: Co-produced travel information through tourist-local social media exchange. Int. J. Contemp. Hosp. Manag. 2017, 29, 690-708. [CrossRef]

58. Lin, P.M.C.; Fan, D.X.F.; Zhang, H.Q.; Lau, C. Spend less and experience more: Understanding tourists' social contact in the Airbnb context. Int. J. Hosp. Manag. 2019, 83, 65-73. [CrossRef]

59. Choi, S.; Fu, X. Hosting friends and family as a sojourner in a tourism destination. Tour. Manag. 2018, 67, 47-58. [CrossRef]

60. Choi, S.; Tam, L.; Ayhan, K.J.; Lee, D. Why and how do sojourners talk about Macao? Effects of perceived risk and expected benefit. Asian Int. Stu. Rev. 2019, 20, 29-51. [CrossRef]

61. Vibber, K.; Kim, J.-N. Advocates or adversaries? Explicating within-border foreign publics' role in shaping soft power through megaphoning and echoing. Place Brand. Public Dipl. 2019. [CrossRef]

62. Yun, S.-H.; Vibber, K. The strategic values and communicative actions of Chinese students for sociological Korean public diplomacy. Int. J. Strateg. Commun. 2012, 6, 77-92. [CrossRef]

63. Melissen, J. The New Public Diplomacy: Soft Power in International Relations; Palgrave Macmillan: New York, NY, USA, 2005.

64. Fitzpatrick, K.U.S. Public Diplomacy in a Post-9/11 World: From Messaging to Mutuality; Figueroa Press: Los Angeles, CA, USA, 2011.

65. Payne, J.G. Trends in global public relations and grassroots diplomacy. Am. Behav. Sci. 2009, 53, 487-492. [CrossRef]

66. Payne, J.G.; Sevin, E.; Bruya, S. Grassroots 2.0: Public diplomacy in the digital age. Com. Pública 2011, 6, 45-70. [CrossRef]

67. Choi, S.; Wu, H.-C. Tourism communicative actions of sojourners and information recipients. J. Dest. Mar. Manag. 2018, 9, $279-287$. [CrossRef]

68. Choi, S.; Iaquinto, B.L.; Wong, C.U.I. Sojourners in Macau: Blurring binaries of home/away and work/leisure. Leis. Stud. 2020, 39, 811-824. [CrossRef]

69. Griffin, T. Immigrant hosts and intra-regional travel. Tour. Geogr. 2017, 19, 44-62. [CrossRef]

70. Mattsson, K.T.; Cassel, S.H. Immigrant entrepreneurs and potentials for path creating tourism development in rural Sweden. Tour. Plan. Dev. 2020, 17, 384-403. [CrossRef]

71. Hart, S.L.; Sharma, S. Engaging fringe stakeholders for competitive imagination. Acad. Manag. Exec. 2004, 18, 7-18.

72. Lalicic, L.; Önder, I. Residents' involvement in urban tourism planning: Opportunities from a smart city perspective. Sustainability 2018, 10, 1852. [CrossRef]

73. Patton, M.Q. Qualitative Research \& Evaluation Methods: Integrating Theory and Practice, 4th ed.; SAGE: London, UK, 2015.

74. Creswell, J.W.; Poth, C.N. Qualitative Inquiry and Research Design-Choosing among Five Approaches, 4th ed.; SAGE: London, UK, 2016.

75. Braun, V.; Clarke, V.; Terry, G. Thematic analysis. In Qualitative Research in Clinical and Health Psychology; Rohleder, P., Lyons, A., Eds.; Palgrave Macmillan: New York, NY, USA, 2014; pp. 95-113.

76. Moon, S. The effect of cultural tourism experience of immigrant women in multi-cultural family. J. Tour. Manag. Res. 2014, $18,85-113$.

77. Munoz, J.R.; Griffin, T.; Humbracht, M. Towards a new definition for "visiting friends and relatives". Int. J. Tour. Res. 2017, 19, 477-485. [CrossRef]

78. Janta, H.; Christou, A. Hosting as social practice: Gendered insights into contemporary tourism mobilities. Ann. Tour. Res. 2019, 74, 167-176. [CrossRef]

79. Yoo, J.P.; Kim, H.; Han, K.-H. Community-based social service utilization of marriage migrants in Korea: Focusing on differences by women's country of origin. Soc. Sci. J. 2020, 57, 39-57. [CrossRef]

80. Amato, F.; Moscato, V.; Picariello, A.; Sperlí, G. Multimedia social network modeling: A proposal. In Proceedings of the 2016 IEEE Tenth International Conference on Semantic Computing (ICSC), Laguna Hills, CA, USA, 4-6 February 2016 ; pp. 448-453.

81. Amato, F.; Moscato, V.; Picariello, A.; Sperlí, G. KIRA: A system for knowledge-based access to multimedia art collections. In Proceedings of the 2017 IEEE 11th International Conference on Semantic Computing (ICSC), San Diego, CA, USA, 30 January-1 February 2017; pp. 338-343. 